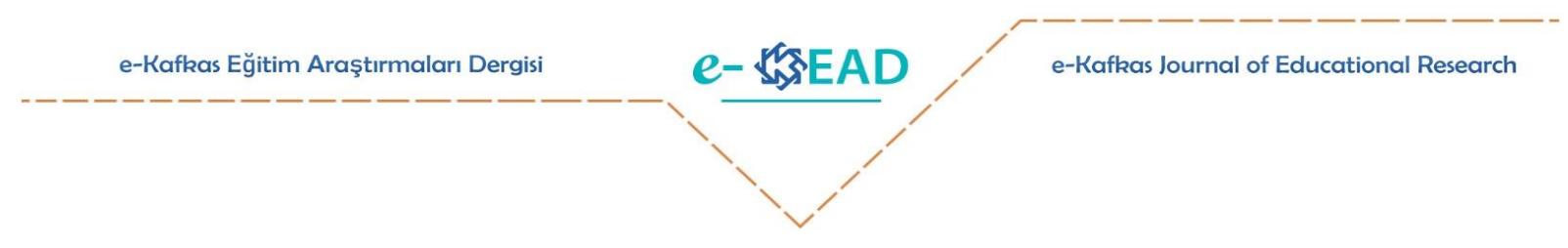

\title{
Okul Öncesi Öğretmen Adaylarının, Öğretmenlerinin ve Öğretim Elemanlarının "Öğretmenlik Uygulaması" Sürecinde Yaşadıkları Zorlukların İncelenmesi ${ }^{1}$
}

\author{
Esra Akgül (iD) Fulya Ezmeci $\mathbb{B}$ Berrin Akman
}

Atıf: Akgül, E., Ezmeci, F. ve Akman, B. (2020). Okul öncesi öğretmen adaylarının, öğretmenlerinin ve öğretim elemanlarının "öğretmenlik uygulaması" sürecinde yaşadıkları zorlukların incelenmesi. e- Kafkas Ĕgitim Araştırmaları Dergisi, 7, 167-184. doi:10.30900/kafkasegt.701585

Araştırma Makalesi

Geliş Tarihi: 10.03 .2020

Kabul Tarihi:12.07.2020

$\ddot{O} \mathbf{z}$

$\mathrm{Bu}$ araştırmada öğretmenlik uygulamasında yaşanan zorlukları ve uygulamanın niteliğinin artırılması için neler yapılabileceğini belirlemek amaçlanmıştır. Çalışma temel nitel araştırma deseninde gerçekleştirilmiş ve okul öncesi eğitim anabilim dalında öğrenim gören dördüncü sınıf öğretmen adayları, okul öncesi öğretmenleri ve öğretim elemanları ile görüşmeler yapılmıştır. Görüşme formu, gözlem formu ve kontrol listesi veri toplama aracı olarak kullanılmıştır. Görüşmelerde öğretmen adaylarına; uygulamalar sırasında yaşanan zorluklar, teorik derslerin sürece yansıması, yeterli ya da donanımlı hissedilen alanlar, mesleki açıdan kazanımlar ve uygulamanın iyileştirilmesi adına önerilerinin neler olduğuna ilişkin sorular sorulmuştur. Okul öncesi öğretmenlerine ise uygulamalar esnasında yaşanan zorluklar, üniversiteyle iletişim, öğretmen adaylarının yaşadığı sorunlar ve bunlara yönelik olası çözümler ve mesleki açıdan öğretmene sunduğu olanaklara ilişkin sorular yönlendirilmiştir. Öğretmenlere yönlendirilen sorular; öğretmen adaylarını haftada en az bir kez gözlemleyerek dönütler veren uygulama sorumlusu öğretim elemanlarına da yöneltilmiștir. Ayrıca gözlem formu ve kontrol listesi araștırmacılar tarafından sekiz hafta boyunca en az yarım gün gözlem yapılarak ve öğretmen adaylarının bu süreçte hazırlamış oldukları tüm planlar incelenerek doldurulmuştur. Veriler tümevarımsal analiz yöntemi ile analiz edilmiştir. Araştırma sonucunda öğretmenlik uygulamalarında yaşanan sorunların temel olarak öğretmen adaylarından, öğretmenden, üniversite ve lisans eğitiminden, atama süreci ile ilgili kaygılardan ve okuldan kaynaklı nedenlerden dolayı ortaya çıktığı görülmüştür. Gözlem notları ve kontrol listelerinden elde edilen bulgular genel olarak tüm paydaşların görüşleriyle paralellik göstermektedir.

Anahtar Sözcükler: Okul öncesi eğitim, okul öncesi öğretmeni, okul öncesi öğretmen adayı, staj uygulaması.

\section{Abstract}

This research aims to determine the difficulties in teaching practices and the ways to improve them. The fourthgrade prospective teachers in the Department of Early Childhood Education, the preschool teachers, and the instructors were interviewed. Interview, observation, and checklist forms were used as data collection tools. The prospective teachers were asked questions about the difficulties encountered during the practices, the reflection of theoretical lessons on the process, the moments when they felt competent and equipped, professional outcomes, and suggestions for improving the practices. The preschool teachers were asked questions about the difficulties during the practices, communication with the university, the problems faced by the prospective teachers and possible solutions to these problems, and the professional opportunities for the teachers. The questions were also asked to the instructors oberving the prospective teachers and giving feedback at least once a week. The observation form and the check list were filled by the researchers by performing at least a half day observation during eight weeks and examining all plans prepared by the prospective teachers. The data were analyzed by inductive analysis method. The study revealed the problems of teaching practices basically resulted from the prospective teachers, teachers, university and undergraduate education, concerns about the appointment process and school. The findings obtained from the observations and check lists are generally consistent with the opinions of all participants. Suggestions on undergraduate education and teaching practices are presented in detail on participant basis in the findings of the study.

Keywords: pre - school education, preschool teacher, preschool teacher candidate, teaching practice

${ }^{1} \mathrm{Bu}$ çalışma 5. Uluslararası Okul Öncesi Eğitim Kongresi’nde sözlü bildiri olarak sunulmuştur. 


\section{Giriş}

Eğitim fakültelerinin tüm bölümlerinde öğretmen adayları; öğretmenlik deneyimi kazanmak, öğretmenlik mesleğinin yeterliliklerini geliştirebilmek, kendi alanlarını tam anlamıyla uygulamalı olarak öğrenebilmek, eğitim öğretim faaliyetlerini gözlemleme, planlama ve uygulama becerisi edinmek amacıyla ögretmenlik uygulamalarına tabi tutulmaktadırlar.

Öğretmenlik uygulamalarının niteliğinin artırılması geleceğe dönük eğitimin kalitesinin artırılmasıyla doğrudan ilişkilidir çünkü öğretmen eğitiminde öğretmenlik uygulaması dersi öğretmen adaylarına önemli kazanımlar sağlamaktadır. Yapılan çalışmalarda öğretmen adaylarının, öğretmenlik uygulamasının sonrasında öğretmenlik mesleğinin etik değerlerine ilişkin algılarının anlamlı düzeyde farklılaştığ (Şişman ve Acat, 2003), eğitim öğretimle ilgili deneyim kazanmakla birlikte (Yıldırım, Özyılmaz Akamca, Ellez, Karabekmez ve Bulut Üner, 2019) kişisel özelliklerinin geliştiği (Çiçek ve İnce, 2005) ve uygulamaların hem kişisel hem de mesleki yeteneklerini geliştirmede etkili olduğu (Kılıç, 2004) sonuçlarına ulaşılmıştır. Bu bağlamda öğretmenlik uygulamasının öğretmen adaylarının mesleki tecrübe, öğretmenlik mesleğini anlama ve anlamlandırmalarında çok önemli bir rol oynadığı söylenilir.

Ayrıca öğretmen eğitimi ve mesleki gelişimi açısından değerlendirildiğinde, yurtdışında yapılan çalışmalar da, uygulama okullarında yürütülen öğretmenlik uygulamalarının öğretmenlerin gelişimi üzerinde etkili olduğunu göstermektedir (Beck ve Kosnik, 2002; Brooks, 2006; Burton, 1998). Bunla birlikte öğretmenlik uygulaması kapsamında öğretmen adaylarına rehber olarak belirlenen öğretmenlerin nitelikli bir rehberlik gerçekleştireceği düşünülmektedir. Ancak bu konuda yapılan araştırmaların bir kısmı öğretmenlerin rehberlik etme konusunda yetersiz olduklarını ifade etmişlerdir (Cansaran, İdil ve Kalkan, 2006; Ergün ve Özdaş, 1999; Kiraz ve Yıldırım, 2007; Şad, 2010; Turgut, Yılmaz ve Firüzan, 2008). Bu sebeple uygulama öğretmenlerinin niteliği öğretmenlik uygulamasının niteliğini de etkilemektedir. Ayrıca öğretmenlik uygulamasının kalitesinin artırılması için kaliteyi etkilen birincil paydaşlardan olan öğretmenlerin görüş ve önerileri de son derece önem taşımaktadır.

Okul Deneyimi ve Öğretmenlik Uygulaması derslerinin öğretmen yetiştirmedeki önemi, alan yazında birçok araştırmaya konu olmakla birlikte öğretmenlik uygulamasının değerlendirilmesi de birçok çalışmada ele alınmıştır (Baştürk, 2007; Boz ve Boz, 2006; Bulut ve Demircioğlu, 2000; Çetintaş ve Genç, 2005; Genç, Sarıçam ve Bakır, 2001; Güzel ve Cerit, 2006; Güzel ve Oral, 2006; Köroğlu, Başer ve Güneş, 2000). Buna ek olarak, öğretmen adaylarının Öğretmenlik Uygulaması dersi ile ilgili görüş ve değerlendirmelerini ortaya koyan araştırmalar da bulunmaktadır (Avcı ve İbret, 2016; Baştürk, 2007; Boz ve Boz, 2006; Bulut ve Demircioğlu, 2000; Büyükgöze Kavas ve Bugay, 2009; Değirmençay ve Kasap, 2013; Demir ve Çaml1, 2011; Eraslan, 2009; Koç ve Yıldız, 2012; Şahin, 2003). Bu çalışmalar incelendiğinde değerlendirmelerin sadece öğretmen adaylarının görüşleri doğrultusunda yapıldığı görülmektedir.

Kuram ve uygulama arasındaki bağı güçlendirmek ve öğretmen adaylarına mesleki gelişimleri için destek sağlamak amacıyla öğretmen eğitiminde, üniversiteler ve uygulama okullarının birlikte çalışması gerektiğinin altı çizilmektedir (Kasapoğlu, 2015). Öğretmenlik uygulaması öğretmen adayı, öğretmen ve öğretim elemanlarını kapsayan çok boyutlu bir süreçtir. Bu süreci sadece bir paydaş açısından incelenmek diğer bakış açılarının göz ardı edilmesine sebep olacaktır. Mevcut çalışmada yapılan uygulamalarda öğretmen adaylarını gözlemleyerek uygulamalarına geri bildirimler veren öğretim elemanlarının da görüşlerinden faydalanılmıştır. Bu nedenle mevcut çalışmada alan yazından farklı olarak diğer paydaşların bakış açıları da dahil edilerek çok boyutlu bir değerlendirme yapılmış ve üç farklı paydaşın görüşleri harmanlanarak bir sonuca ulaşılmaya çalışılmıştır.

Alan yazın incelendiğinde öğretmenlik uygulamalarını bu üç paydaş özelinde değerlendiren Seçer, Çeliköz ve Kayılı (2010)'nın çalışmalarına rastlanmıştır. Ancak bu çalışmanın 2010 yılında yapıldığ1 görülmektedir. Okul öncesi eğitim programı bu tarihten sonra değişikliğe uğramış, bu değişiklik doğrultusunda öğretmenlik uygulamalarının içeriğinde de değişiklikler yapılmıştır. Mevcut çalışma bu araştırmadan farklı olarak güncel öğretmenlik uygulamalarında yaşanan zorluklar, nedenleri ve çözüm önerileri bağlamında alan yazına katkı sağlayacağı düşünülmektedir. Ayrıca Seçer, Çeliköz ve Kayılı (2010) yaptıkları çalışmada yaşanılan sorunlar ve çözüm önerilerini irdelemiştir. Ancak mevcut çalışma karşılaşılan zorluklar, zorlukların nedenleri ve bu sürecin paydaşlara mesleki açıdan neler kazandırdıklarına ilişkin alt boyutları ile de alan yazına katkı sağlayacağı düşülmektedir. Ayrıca 
bu çalışmada alan yazından farklı olarak elde edilen görüşme bulguları neticesinde oluşturulan gözlem formu ve kontrol listesiyle yapılan gözlem notları ve plan değerlendirmeleriyle bulgular güçlendirilmiş̧tir. Tüm bu bilgilerin ışı ğında bu çalışmada öğretmenlik uygulamasında yaşanan zorluklar ve uygulamanın daha iyi olması için neler yapılabileceğini belirlemek amaçlanmıştır. Bu hedef doğrultusunda aşağıdaki sorulara cevaplar aranmıştır:

1- Öğretmenlik Uygulamasında yaşanan zorluklar nelerdir?

2- Yaşanan bu zorlukların nedenleri nelerdir?

3- Bu zorluklara yönelik çözüm önerileri nelerdir?

4- Öğretmenlik Uygulamasının mesleki açıdan katkıları nelerdir?

5- Yaşanan zorluklar, nedenleri ve çözüm önerileri paydaşlar bazında ne tür benzerlikler ve farklılıklar göstermektedir?

\section{Yöntem}

Bu çalışma nitel araştırma yöntemlerinden temel nitel araştırma deseninde tasarlanmıştır. Temel nitel araştırmalar; verilerin gözlem, görüşme veya doküman incelemesi yoluyla elde edildiği yaygın nitel araştırma biçimleridir. Bu desende sorulacak sorular, nelerin gözlemleneceği, dokümanlardan hangilerinin ilişkili kabul edileceği çalışmanın teorik çerçevesine bağlıdır. Temel nitel araştırmalarda verilerin analizinde veriyi karakterize ederek tekrar eden örüntüler belirlenir (Merriam, 2013).

\section{Katılımcilar}

Çalışmada bir devlet üniversitesi temel eğitim ana bilim dalında eğitim gören 18 son sınıf öğretmen adayı, öğretmen adaylarının uygulama yaptıkları sınıflardaki mesleki kıdemleri 6 ila 36 yıl arasında değişen, üniversite mezunu 19 okul öncesi öğretmeni ve öğretmen adaylarının uygulamalarını sistematik olarak gözlemleyen ve öğretmen adaylarına dönütler veren 8 öğretim elemanı ile görüşmeler yapılmıştır. Araştırmanın katılımcıları, amaçlı örnekleme yöntemlerinden ölçüt örnekleme yoluyla seçilmiştir. Katılımcıların lisans son sınıf olmaları ve öğretmenlik uygulaması dersini alıyor olmaları ölçüt olarak belirlenmiştir. Bu ölçüt bazında belirlenen lisans öğrencilerinin uygulama yaptıkları okullarda tabii oldukları öğretmenler ve bu ders sürecinde bağlı oldukları öğretim elemanları çalışmaya dahil edilmiştir.

\section{Çalışmanın Kapsamı}

Bu bölümde araştırmanın yapıldığı üniversitede uygulanan öğretmenlik uygulaması hakkında bilgiler sunulmuştur. Öğretmenlik Uygulamasının içeriği: öğretmen adayları lisans eğitimleri süresince, 2. dönem haftada 1 yarım gün 'gözlem', 6. dönem haftada 1 yarım gün 'okul deneyimi', 7. dönem haftada 2 yarım gün ve 8 . dönem haftada 3 yarım gün 'öğretmenlik uygulaması' olmak üzere uygulama eğitimi almaktadırlar.

Son sınıfta aldıkları öğretmenlik uygulamasında her yarım gün için 2 etkinlik planı hazırlamaları beklenmektedir. Planlarını, öğretmenlerin aylık planları ve öğretmenlerin beklentileri doğrultusunda hazırlayarak, uygulamadan en az 2 gün önce sorumlu öğretim elemanına göstermeleri gerekmektedir. Sorumlu öğretim elemanın verdiği dönütler doğrultusunda planlar düzeltilerek öğretim elemanına onaylatıldıktan sonra uygulamaya gidilmektedir. Uygulamada ise sorumlu öğretim elemanı haftada en az bir yarım gün staj okuluna giderek öğretmen adaylarının uygulamalarını gözlemlemekte ve aynı gün dönütler vermektedir.

\section{Veri Toplama Aracı}

Çalışmadaki veriler; nitel araştırmalarda kullanılan veri toplama yöntemlerinden görüşme, gözlem ve doküman incelemesi yoluyla elde edilmiştir. Görüşme sonuçlarını desteklemek ve kontrol etmek amacıyla görüşmeler neticesinde elde edilen bulgular doğrultusunda öğretmen adaylarına yönelik gözlem formları ve kontrol listeleri oluşturulmuştur. Bu formlar ile görüşme sonuçlarından elde edilen verilerin teyidi sağlanmıştır.

Öğretmenler, öğretmen adayları ve uygulama öğretim elemanları için araştırmacılar tarafından ayrı ayrı geliştirilen, yarı yapılandırılmış sorulardan oluşan "Görüşme Formu” kullanılmıştır. 
Öğretmenler için oluşturulan görüşme formunun birinci bölümünde mesleki kıdem ve en son mezun olunan eğitim derecesi bilgilerine yer verilirken; yarı yapılandırılmış sorulardan oluşan ikinci kısımda ise uygulamalar sırasında yaşanan zorluklar (kendileri ve öğretmen adaylarının yaşadıkları), bu zorlukların nedenleri, çözüm önerileri ve mesleki açıdan kendilerine katkısı olup olmadığına ilişkin soruları içermektedir. Geçerliği sağlayabilmenin yollarından birisi olan inandırıcılığı (Creswell, 2014; Creswell ve Clark, 2011; Yıldırım ve Şimşek, 2013) sağlamak adına uzman görüşleri alınmıştır. Çalışmada bu bağlamda nitel araştırma yöntemini kullanarak araştırmalar yapmış ve nitel araştırmalara yönelik eğitim vermekte olan 3 alan uzmanının görüşlerine başvurulmuştur. Alan uzmanları soruları; dili, içeriği ve nitel çalışmaların doğasına uygunluğu yönlerinden değerlendirmişlerdir. Değerlendirme sonucunda uzmanların önerileri doğrultusunda dil ve içeriksel düzeltmeler yapılmıştır.

Öğretmen adayları ve öğretim elemanları için oluşturulan görüşme formları, görüşme sorularının yer aldığı tek bölümden oluşmaktadır. Öğretmen adaylarına uygulamalar sırasında yaşanan zorluklar, bu zorlukların nedenleri, çözüm önerileri ve mesleki açıdan kendilerine katkısının olup olmadığı sorulurken öğretim elemanlarına uygulamalar sırasında yaşanan zorluklar (kendileri, öğretmen ve öğretmen adaylarının yaşadıkları), bu zorlukların nedenleri, çözüm önerileri ve mesleki açıdan kendilerine katkısının olup olmadığına ilişkin sorular yer almaktadır. Bu aşamadan sonra elde edilen bulgular doğrultusunda gözlem formu ve kontrol listesi oluşturulmuştur.

Gözlem formu ve kontrol listesi oluşturulurken; öğretmen adayları, öğretmenler ve öğretim elemanlarının görüşleri doğrultusunda öğretmen adaylarının yaşadıkları zorluklar listelenmiştir. Oluşturulan bu listede hazırlanan planlar ve uygulama sürecine yönelik iki farklı boyut ortaya çıkmıştır. Yapılan görüşmelerde elde edilen verilerin tutarlılığının kontrol edilmesi amacıyla gözlem formu ve kontrol listesi oluşturulmuştur. Gözlem formları öğretmen adayının uygulaması sırasında gözlem yaparken; kontrol listeleri ise hazırlanan planları incelerken kullanılmıştır.

\section{Verilerin Toplanması}

Görüşmeler yüz yüze gerçekleştirilmiş̧ir. Her bir görüşme yaklaşık 25 dakika sürmüştür. Görüşmeden elde edilen veriler analiz edilerek hazırlanan gözlem formu ve kontrol listesi araştırmacılar tarafından 8 hafta boyunca en az bir yarım gün gözlem yapılarak ve öğretmen adaylarının bu süreçte hazırlamış oldukları tüm planlar (864 etkinlik planı) incelenerek doldurulmuştur. Bu gözlem ve doküman incelemesiyle çalışmada elde edilen bulguların desteklenmesi amaçlanmıştır.

\section{Verilerin Analizi}

Analiz sürecine geçilmeden önce yapılan görüşmeler deşifre edilmiştir. Daha sonra görüşmelerden elde edilen verilerin analizi gerçekleştirilmiştir. Analiz sürecinde temalar önceden belirlenmemiş, yapılan görüşmelerden kodlar oluşturulmuş, bu kodlardan temalar ve kategorilere ulaşılarak tümevarımsal analiz yapılmıştır. Araştırmanın güvenirliğini sağlamak için veriler üç araştırmacı tarafindan kör bir şekilde incelenerek analiz edilmiş, ardından araştırmacılar bir araya gelerek kodları karşılaştırmış ve farklı kategorilere atfedilen kodlar üzerinde üç araştırmacının da mutabık olduğu kodlar nihai olarak alınmıştır. Daha sonra araştırmacılar bir araya gelerek ortak görüşleri doğrultusunda analizleri birleştirmişlerdir. Analizler neticesinde elde edilen bilgiler baz alınarak gözlem formu ve kontrol listesi oluşturulmuştur. Daha sonra gözlem formu ve kontrol listesinden elde edilen veriler ile görüşmelerden elde edilen verilerin tutarlı olup olmadığına bakılmış, karşılaştırmalı olarak analiz edilmiştir. $\mathrm{Bu}$ analizler sonucunda görüşmelerden elde edilen verilerin kontrol listesi ve gözlem formlarından elde edilen veriler ile desteklendiği görülmüştür. Araştırmanın bulgularında aynı sonuçlara ulaşıldığ için görüşmelerden elde edilen veriler sunulmuştur.

\section{Bulgular}

Analizler sonucunda elde edilen bulgular; öğretmen adaylarının yaşadıkları zorluklar, öğretmen ve öğretim elemanlarının yaşadıkları zorluklar, yaşanan zorlukların nedenleri, staj önerileri ve mesleki kazanımlar şeklinde dört başlık altında toplanmıştır. Bu başlıklar altında elde edilen kategorilere ve temalara ilişkin bulgular tablolar şeklinde sunulmuştur. Ayrıca her bir bulguda yaşanan zorluklar, nedenleri ve çözüm önerileri paydaşlar bazında ne tür benzerlikler ve farklılıklar gösterdiği sunulmuştur.

\section{Öğretmen Adaylarının Yaşadıkları Zorluklar}


Öğretmen adaylarının yaşadığı zorluklar incelendiğinde yaşanan zorlukların temel olarak öğretmen adayından kaynaklı, uygulama öğretmeninden kaynaklı, üniversiteden kaynaklı, atama süreci ile ilgili kaygılardan kaynaklı ve diğer kategorilerinde toplandığı görülmüş̧ür.

Tablo 1.

Öğretmen Adayından Kaynaklanan Zorluklar

\begin{tabular}{lccc}
\hline \multicolumn{1}{c}{ Zorluklar } & Öğretmen Adayı & Öğretim Elemanı & Öğretmen \\
\hline Plan yazmakta zorlanma & $*$ & $*$ & $*$ \\
\hline Çocukların seviyesine uygun plan hazırlayamama & $*$ & $*$ & $*$ \\
\hline Problem davranış gösteren çocuklara müdahale & $*$ & $*$ & $*$ \\
\hline Küçük grup etkinlikleri hazırlama da eksiklik & $*$ & $*$ & $*$ \\
\hline Etkinlikler arası geçiş & $*$ & $*$ & $*$ \\
\hline Teoriği pratiğe geçirememe & $*$ & $*$ & $*$ \\
\hline Sınıf yönetiminde zorluk & $*$ & $*$ & $*$ \\
\hline Etkinlik çeşitliliği & $*$ & $*$ & $*$ \\
\hline Uygulamada zorluk & $*$ & $*$ & $*$ \\
\hline Diğer kurumlardan gelen öğretmen adayları & $*$ & $*$ & $*$ \\
\hline Çocukların aşırı hareketli olması & $*$ & $*$ & $*$ \\
\hline Uyarlama/aile katılımı yazmakta zorluk & $*$ & $*$ & $*$ \\
\hline Materyal üretememe & & & $*$ \\
\hline Yaratıcı düşünmede zorluk & & & $*$ \\
\hline Çocuklarla etkili iletişim kuramama & & $*$ \\
\hline Karma yaş gurupları & & $*$ \\
\hline Çocuklarla iletişim & & $*$ \\
\hline Kaynaştırma & & $*$ \\
\hline Beklenmedik durumda müdahale eksikliği & & $*$ \\
\hline
\end{tabular}

Tablo 1'de öğretmen adayı, öğretim elemanı ve öğretmenler bazında öğretmen adaylarından kaynaklanan zorluklar ifade edilmiştir. Tüm paydaşların ortak olarak belirttiği öğretmen adayından kaynaklanan zorluklar ise şunlardır: plan yazmakta zorlanma, çocukların seviyesine uygun plan hazırlayamama, etkinlik çeşitliliği, küçük grup etkinlikleri hazırlamada eksiklik, etkinlikler arası geçiş, teoriği pratiğe geçirememe, sınıf yönetiminde zorluk, problem davranış gösteren çocuklara müdahale, uygulamada zorluk, diğer kurumlardan gelen öğretmen adayları.

Araştırmacılar tarafından incelenen plan değerlendirmeleri sonucunda ise öğretmen adaylarının plan yazmada ve çocukların yaş gruplarına uygun etkinlik hazırlamada zorluklar yaşadıkları sonucuna ulaşılmıştır. Buna ek olarak küçük grup etkinliklerinin hem planlama hem de uygulama sürecinde öğretmen adaylarının tamamına yakınının zorluklar yaşadığı görülmüştür. Etkinlik çeşitliliğine bakıldığında ise öğretmen adaylarının drama, fen, hareket ve alan gezisi etkinliklerine 8 hafta boyunca planlarında çok az yer verdikleri görülmüştür. Gözlem sonuçları ise; yukarıdaki bulgularla birçok noktada paralellik gösterirken, çocuklarla etkili iletişim kuramama ve materyal üretememe zorlukları gözlemlenmemiştir.

Sınıf yönetimine ilişkin bir araştırmacının gözlem notu şu şekildedir: "çocuklardan A., etkinlik sırasında başka bir çocuk konuşurken sözünü kesti, ögretmen adayı Ş. ise tepki olarak sını kuralını çocuğa hatırlatarak arkadaşının sözünü kesmemesi gerektiğini söylemek yerine tüm sinıfa yönelik olarak "herkes sessiz olsun" dedi."

Diğer kurumlardan gelen öğretmen adaylarına ilişkin araştırmacının gözlem notu şu şekildedir: “X üniversitesinden gelen ögrretmen adayının uygulaması uzun sürdüğ̈̈ için ögrretmen adayı S.'nin uygulaması yarım kaldı", "diğer kurumlardan gelen ögretmen adayı uygulama yaptığı için H. Uygulama yapamadı" 
Tablo 2.

Öğretmenden Kaynaklanan Zorluklar

\begin{tabular}{ll}
\hline Öğretmen Adayı & Öğretmen adayı ve Öğretim Elaman \\
\hline Öğretmenle iletişim sorunu & Sınıfta yalnız kalmaları \\
Etkinliği planlandığı gibi yapamamak & Öğretim elemanı ve öğretmenin beklentilerinin farklı \\
Öğretmenin aşırı müdahalesi & olmas \\
Etkinliklerde planlanan materyallerin değiştirilmesi & Öğretmenin rehberlik etmemesi/dönüt vermemesi \\
Etkinlik uygulama aşamasında diğer yetişkinlerin & Sorumluluklarının dışında beklentiler. \\
gürültü yapmasından kaynaklı uygulamada zorluk & \\
Etkinlik uygulamasında etraf kirleniyor diye negatif & \\
tavır takınılması & \\
Stajyer abla olarak tanıtılması & \\
\hline
\end{tabular}

Tablo 2'de öğretmen adayı açısından öğretmenden kaynaklanan zorluklar ifade edilmiştir. Öğretmen adayı ve öğretim elemanlarının ortak olarak belirttiği öğretmenden kaynaklanan zorluklar ise şunlardır: Sınıfta yalnız kalmaları, Öğretim elemanı ve öğretmenin beklentilerinin farklı olması (tematik-kazanım, sınıf süsleme), Öğretmenin rehberlik etmemesi/dönüt vermemesi, sorumluluklarının dışında beklentiler. Öğretmenlerin verdikleri yanıtlardan bu kategori için herhangi bir bulguya rastlanmamıștır.

Gözlem bulgularında da benzer sonuçlar elde edilirken; Öğretmenle iletişim sorunu ve etkinliklerde planlanan materyallerin değiştirilmesi gözlemlenmemiştir. Öğretmenden kaynaklanan zorluklara ilişkin bir araştırmacının gözlem notları şu şekildedir: "Sınıftaki çocuklar ögrretmen adayı Z'ye "Z abla" şeklinde seslenmektedirler", "Öğretmen adayı sanat etkinliği uygulamasın yaparken diğer sinif ögretmenlerinden P. ve N. Sinifa kahvelerle gelerek uygulama boyunca sohbet etmişlerdir", "Ögretmen uygulama sırasında aşırı müdahale etti. T. Etkinliğe çok motive başlamıştı ancak etkinlik ortalarında ve sonuna doğru isteksiz olmaya başladl."

Tablo 3.

Üniversiteden Kaynaklanan Zorluklar

\begin{tabular}{ll}
\hline Öğretmen Adayı & Öğretmen \\
\hline Her hafta plan göstermek & Uygulamanın 3 gün olması \\
Staj yönergesinin yetersiz olması & \\
Staj uygulamasının yoğun olması & \\
\hline
\end{tabular}

Tablo 3'te üniversiteden kaynaklanan nedenler öğretmen adayı ve öğretmenler bazında belirtilmiştir. Öğretim elemanları ile yapılan görüşmelerde bu kategoriye ilişkin herhangi bir bulguya rastlanmamıştır.

Tablo 4.

Atama Süreci İle İlgili Kaygılardan Kaynaklanan Zorluklar

\begin{tabular}{ll}
\hline Öğretmen Adayı & Öğretim elemanları \\
\hline Kamu Personeli Seçme Sınavından (KPSS) & Okullara ulaşım \\
\hline
\end{tabular}

Tablo 4'te Atama süreci ile ilgili kaygılardan kaynaklı zorluklara ilişkin öğretmen adayları Kamu Personeli Seçme Sınavından (KPSS) bahsederken, öğretim elemanları okullara ulaşım probleminden bahsetmişlerdir. Öğretmenler ise bu konuda herhangi bir görüş belirtmemişlerdir.

\section{Öğretmenler ve Öğretim Elemanlarının Yaşadıkları Zorluklar}

Öğretmenler ve öğretim elemanlarının yaşadığı zorluklar boyutunda yaşanan zorluklar ait bulgular Tablo 5'te sunulmuştur. 
Tablo 5.

Öğretim Elemanları ve Öğretmenlerin Yaşadıkları Zorluklar

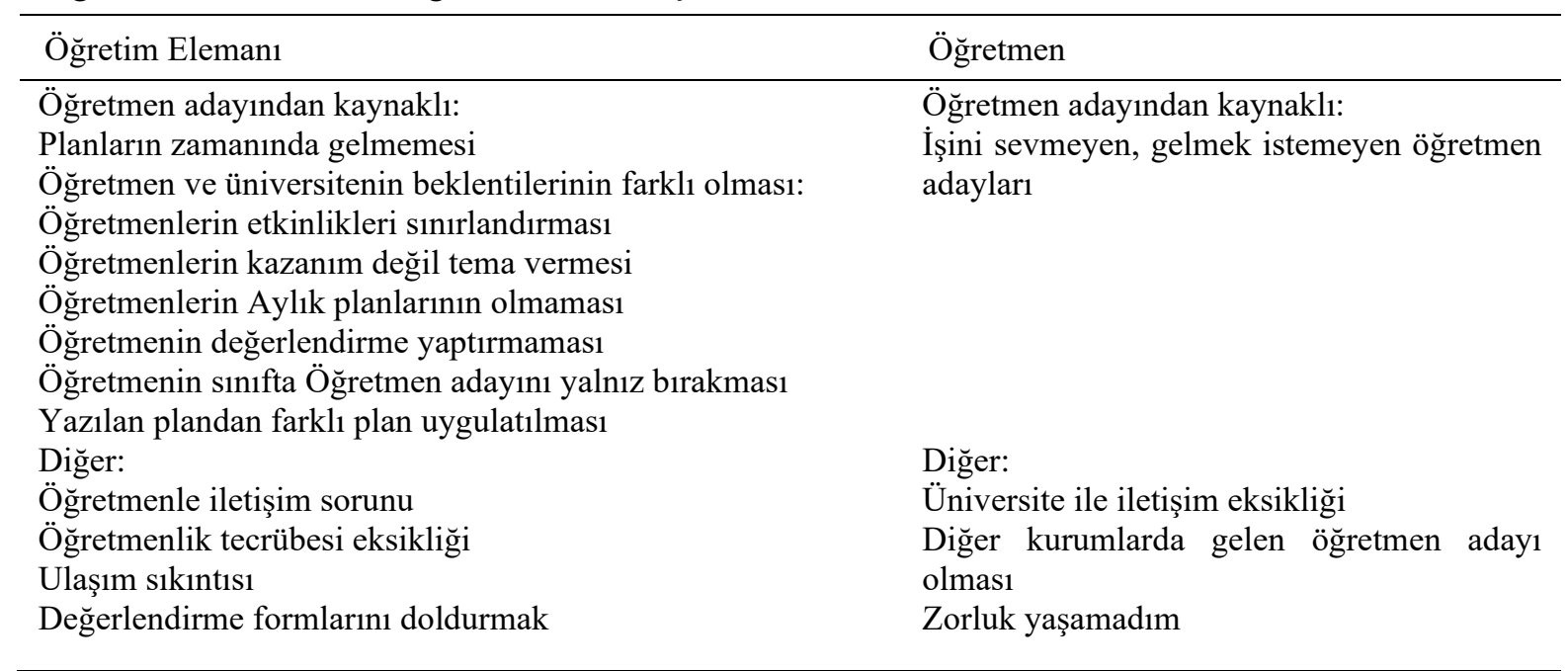

Tablo 5’te öğretim elemanları ve öğretmenlerin Öğretmenlik Uygulamasında yaşadıkları zorluklar belirtilmiştir. Öğretim elemanlarının öğretmen adaylarından, öğretmen ve üniversitenin beklentilerinin farklı olmasından ve diğer sebeplerden zorluklar yaşadıklarını söylerken; öğretmenlerin öğretmen adayından ve diğer sebeplerden zorluk yaşadıklarını söylemişlerdir. Bazı öğretmenler ise zorluk yaşamadıklarını belirtmişlerdir.

\section{Yaşanan Zorlukların Nedenleri}

Yaşanan zorlukların nedenleri alt boyutu incelendiğinde öğretmen adayından kaynaklı, uygulama öğretmeninden kaynaklı, üniversiteden kaynaklı ve uygulama okulundan kaynaklı nedenler kategorileri oluşmuştur. Öğretmen adayından kaynaklı nedenler kategorisine ait temalar tablo 5'de sunulmuştur.

Tablo 6.

Öğretmen Adayından Kaynaklanan Nedenler

\begin{tabular}{|c|c|}
\hline Öğretim Elemanı & Öğretmen \\
\hline Çekingen olmaları & İşbirlikçi olmama (Sınıfı sahiplenmeme) \\
\hline Çocukları yeterince tanımamaları & Uygulamayı sinıf geçmeleri gerek bir ders \\
\hline Sonuca ve ürüne odaklanma & olarak görme \\
\hline Programı tam olarak öğrenmemiş olmaları & \\
\hline
\end{tabular}

Tablo 6'da öğretmen adayından kaynaklanan nedenler; öğretim elemanı ve öğretmen bazında ifade edilmiştir. Öğretim elemanı, öğretmen ve öğretmen adayları ise ortak olarak; Sınıf yönetimi becerilerinde eksiklik, tecrübesizlik ve teorik bilginin pratiğe yansıtılamamasını neden olarak belirtmişlerdir. Öğretmenler, öğretmen adayından kaynaklanan nedenlere sınıfı sahiplenmeden kaynaklı işbirlikçi olmadıklarını söylerken; öğretim elemanları bunun çekingenlik ve çocukları yeterince tanımamalarından kaynaklı olduğunu belirtmişlerdir.

Araştırmacılar; yukardaki bulgulara benzer gözlem sonuçları elde etmişlerdir. Ancak öğretmen adaylarının işbirlikçi olmamaları (Sınıfı sahiplenmeme) ve uygulamayı sınıf geçmeleri gerek bir ders olarak gördükleri bulguları gözlemlenmemiştir.

Araştırmacıların gözlem notları şu şekildedir: " $N$. çocukların isimlerini bilmediği için isimleriyle hitap etmiyor.", "A. sanat etkinliği yaparken tüm sinıfin birlikte oluşturacakları akvaryumu tamamlamaya odaklandiğı için çocukların sorularına çok kısa cevaplar verip bir an önce boyama ve kesme işini bitirmelerini söyledi”. 
Tablo 7.

Üniversiteden Kaynaklanan Nedenler

\begin{tabular}{lcc}
\hline & Öğretmen Adayı Öğretim Elemanı & Öğretmen \\
\hline Zamanımızı alması & $*$ & \\
\hline Fiziksel yorgunluk & $*$ & \\
\hline Yoğun olması (3gün) & $*$ & \\
\hline Düzenlemelerinin yetersiz olması & $*$ & \\
\hline Sorumlulukların net tanımlanmaması & \\
\hline $\begin{array}{l}\text { Program dersinin tek dönem olması ve uygulama } \\
\text { basamağının olmaması }\end{array}$ & $*$ \\
\hline Staj gününün az olması & $*$ \\
\hline Her öğretim elemanının beklentisinin farklı olması & \\
\hline Staj gününün az olması & $*$ \\
\hline Derslerin teorik ağırlılı olması & $*$ \\
\hline Lisans sı̈ıfların çok kalabalı olması & $*$ & $*$ \\
\hline Sinıf yönetimi gibi derslere alan hocalarının girmemesi & $*$ & $*$ \\
\hline Alan derslerinin seçmeli olmasını & $*$ & $*$ \\
\hline Staja okulun ilk gününden başlanmaması & $*$ & $*$ \\
\hline
\end{tabular}

Tablo 7'de üniversiteden kaynaklı nedenler paydaşlar bazında ifade edilmiştir. Bunlara ek olarak öğretmen adayları ve öğretim elemanları ortak olarak; Derslerin teorik ağırlıklı olması, Lisans sınıfların çok kalabalık olması, Sınıf yönetimi gibi derslere alan hocalarının girmemesi ve Alan derslerinin seçmeli olmasını neden olarak sunmuşlardır. Ayrıca tüm paydaşlar ortak olarak Staja okulun ilk gününden başlanmamasını üniversiteden kaynaklı neden olarak ifade etmişlerdir.

Tablo 8.

Öğretmenden Kaynaklanan Nedenler

Öğretmen Adayı Öğretim Elemanı

\begin{tabular}{ll}
\hline Öğretmenin etkinliği değiştirmek istemesi & İdeal öğretmen modeliyle çok karşılaşamamaları \\
Ögretmenin baskın tavrı & \\
Öğretmenin öğretmen adayını önemsememesi & \\
Öğretmenlerin kendi aralarındaki rekabet & \\
\hline
\end{tabular}

Tablo 8'de öğretmen adayı ve öğretim elemanı bazında öğretmenden kaynaklanan nedenler ifade edilmiştir. Öğretmen adayı ve öğretim elemanlarının ortak olarak belirttiği öğretmenden kaynaklanan nedenler ise şunlardır: Öğretmenlerin öğretmen adayına yeterince destek olmamaları/ rehberlik etmemeleri, Çocuklar tarafindan abla gibi görülmeleri/ öğretmenin bu şekilde tanıtması ve öğretmenlerin öğretmen adayının görev ve sorumluluklarının dışında beklentilerinin olması şeklinde belirtilmiştir. Öğretmenlerin verdikleri yanıtlardan bu kategori için herhangi bir bulguya rastlanmamıştır.

Tablo 9.

Okuldan Kaynaklanan Nedenler

\begin{tabular}{ll}
\hline Öğretmen Adayı & Öğretmen Adayı ve Öğretim Elemanı \\
\hline $\begin{array}{l}\text { Okul idaresinin öğretmen adayı ile iletişime geçmemesi } \\
\text { Okulun fiziksel imkânlarının yetersizliği }\end{array}$ & Göstȩsli ve görsel etkinliklere çok önem verilmesi \\
\hline
\end{tabular}

Tablo 9'da öğretmen adaylarının okuldan kaynaklanan nedenlerden dolayı yaşadıkları zorluklar yer almaktadır. Öğretmen adayı ve öğretim elemanlarının ortak olarak belirttiği okuldan kaynaklanan neden ise okul idaresinin 'Gösterişli ve görsel etkinliklere çok önem verilmesi' olarak ifade edilmiştir. Öğretmenlerin verdikleri yanıtlardan bu kategori için herhangi bir bulguya rastlanmamıştır. 


\section{Öneriler}

Öğretmenlik uygulamalarının daha etkili ve verimli olması adına öneriler sorulduğunda lisans eğitimine ve öğretmenlik uygulamasına yönelik iki kategori oluşmuştur.

Tablo 10.

Lisans Eğitimine Yönelik Öneriler

\begin{tabular}{|c|c|}
\hline Öğretmen Adayı & Öğretim Elemanı \\
\hline $\begin{array}{l}\text { Alan dersleri gruplara ayrılarak } \\
\text { küçük gruplar şeklinde eğitim } \\
\text { verilmeli } \\
\text { Özellikle program dersi tek } \\
\text { dönem olmamalı ve pratiğe } \\
\text { dönük olmalı }\end{array}$ & $\begin{array}{l}\text { Uygulamaya yeni gidecek araştırma görevlilerine öğretim üyeleri } \\
\text { rehberlik etmeli } \\
\text { Uygulama okulla önceki dönemden belirlenmeli } \\
\text { Öğretmenlere beklentilerimizin ne olduğu daha açık ifade edilmeli } \\
\text { Uygulama okulu olmalı (öğretmenlik tecrübesi olmayan arş. Gör. } \\
\text { Öğretmenlik yapmalı, derslerde anlatılan teoriğin uygulaması bu } \\
\text { sınıflarda yapılmalı) }\end{array}$ \\
\hline
\end{tabular}

Tablo 10'da Lisans eğitimine yönelik öneriler öğretmen adayı ve öğretim elemanı bazında ifade edilmiştir. Bunlara ek olarak öğretmen adayları ve öğretim elemanları ortak olarak; Dersleri alan hocalarının vermesi, Alana dair daha fazla ders alma / bazı seçmeli alan derslerinin zorunlu olması (Kaynaştırma, sanat ve yaratıcılık eğitimi, fen eğitimi, matematik, dil ve kavram gelişimi), Lisans derslerinde uygulama boyutu olmasını öneri olarak sunmuşlardır. Ayrıca tüm paydaşlar ortak olarak öğretmen adaylarına okula uyum süreci hakkında eğitim verilmesini öneri olarak ifade etmişlerdir. $\mathrm{Bu}$ bulguya ilişkin ifadeler aşağıdaki gibidir:

"1. sınıftan itibaren uygulamalı eğitim yapmak daha faydalı olur')(Öğretmen Adayı),"Etkinlik türlerine yönelik farklı uygulamalar görme şansımız olmalı"'(Öğretmen Aday1), "İlk üç sene sürekli teorik ders almak ve son sinıfta tamamen uygulamaya dönmek yerine teorik derslerinde uygulamasının olmalı", (Öğretim Elamanı), "Teorik olarak aldı̆̆ımız dersler bana göre fazlasıyla yeterli. Fakat sınıf içerisinde teorik bilgilerimiz çok havada kalıyor. Biraz daha pratik olarak eğitim verilebilir'’(ögretmen adayı).

Tablo 11.

Öğretmenlik Uygulamasına Yönelik Öneriler

\begin{tabular}{lll}
\multicolumn{1}{c}{ Öğretmen Adayı } & \multicolumn{1}{c}{ Öğretim Elemanı } & \multicolumn{1}{c}{ Öğretmen } \\
\hline Öğretmen-öğretim elemanı & Uygulama okulları önceki & Tam gün olmalı \\
ilețşiminin güçlü olmalı & dönemden belirlenmeli & Alternatif planları olmalı \\
Öğretim elemanı ve Öğretmen & Öğretmenlere beklentilerimizin & \\
adayı daha çok bir araya gelmeli & ne olduğu daha açık ifade & \\
Uygulamada dinlenmek için ara & edilmeli & \\
1 günü gözlem & Dönüt veren rotasyonun & \\
Idari staj & (öğretmen ve Arş. Gör) & \\
\hline
\end{tabular}

Tablo 11'de Öğretmenlik Uygulamasına yönelik öneriler öğretmen adayı, öğretim elemanı ve öğretmenler bazında ifade edilmiştir. Bunlara ek olarak öğretmen adayları saatleri, sorumlulukları), Uygulama daha önceki dönemlerden başlanmalı ve tüm dönemlere yayılmalı, Staj için tercih edilen ögretmenlerin mesleki yeterlilikleri değerlendirilmeli ifadelerini öneri olarak sunmuşlardır. Ayrıca tüm paydaşlar ortak olarak Uygulama okulun ilk gününden başlanmalı, Öğretmenlerle ve okul idaresi ile sık sık toplantılar yapılmalı ve öğretmen adaylarının tüm sürece dahil olmaları (giriş-çıkış) gerektiğini öneri olarak ifade etmişlerdir. 


\section{Mesleki kazanımlar}

Tablo 12.

Öğretmenlik Uygulamalarının Mesleki Açıdan Katkısı

\begin{tabular}{lll}
\hline Öğretmen Adayı & Öğretim Elemanı & Öğretmen \\
\hline Kendine güven & Tecrübe kazanma & Uygulamada güncel bilgiler \\
İnsan ilişkileri düzenleme & Alandaki eksiklikleri görerek & (yeni yaklaşımlar, değişiklikler) \\
İş Ahlakı & akademik çalışmalar için fırsat & Karş1lıklı öğrenme \\
Mesleki gelişim (sınıf & Çocukların ve Öğretmen adaylarının & Farklı bakış açıları \\
yönetimi, çocukla etkili & ihtiyaçlarının farkına varma & Öz denetim \\
iletişim, plan yazma) & Uygulamada güncel bilgiler & 'Örnek olmaya çalıştığım için \\
Tecrübe kazanmak & Teorik dersleri somutlaştırabilmek için & kendimi sürekli denetliyorum’ \\
Öz değerlendirme & birikim & Etkinlik havuzu oluşturma \\
Çocukla iletişim & Öz değerlendirme ve araştırmaya & \\
Yararsız & teşvik & \\
& Yaratıcı düşünme & \\
\hline
\end{tabular}

Öğretmenlik uygulamalarının mesleki açıdan katkısı olup olmadığı alt boyutuna ilişkin bulgular Tablo 12'de sunulmuştur. Genel olarak bakıldığında tüm paydaşların öğretmenlik uygulamalarını mesleki gelişimleri açısından değerli buldukları görülmektedir. Bunun yanı sıra bazı açılardan kişisel gelişimlerine de katkı sağladığını belirttikleri görülmektedir.

\section{Tartışma, Sonuç ve Öneriler}

$\mathrm{Bu}$ bölümde, elde edilen bulgulara ilişkin literatürdeki benzer araştırmalar ele alınmış ve bu araştırmaya benzer/farklı yönleri açısından irdelenmiştir. Daha sonra araştırmaya dahil edilen tüm paydaşların verdikleri yanıtlardaki farklılaşmalar nedenleri irdelenerek tartışılmıştır.

Kasapoğlu (2015) tarafından 2000-2010 yılları arasında okul deneyimi ve öğretmenlik uygulaması üzerine yapılan çalışmaların incelendiği araştırma sonucuna göre öğretmenlik uygulamalarında karşılaşılan sorunlar şunlardır: Etkili rehberlik sağlamada ve okul deneyimi ve öğretmenlik uygulamasında görülen eksiklikler, uygulama öğretmenleri ve öğretmen adayları arasındaki etkileşim sınırlılığı ya da yokluğu, üniversiteler ve uygulama okulları arasındaki işbirliği sinırlılığı ya da yokluğu, öğretmen adaylarının öğretmenlik uygulaması ile algıladıkları yetersizlikleri, öğretmen adaylarının uygulama okullarına yerleştirilmesinde karşılaşılan sorunlar, uygulamaya hazırlık ve sınırlı sürede uygulamanın getirdiği güçlükler, fakülte koordinatörleri ve uygulama öğretim elemanlarının seçimi ve yerleştirilmesi için oluşturulan bir sistemin eksikliği ya da yokluğu, devlet okullarında sunulan olanakların sınırlılığı ya da yokluğu, okul deneyimi ve öğretmenlik uygulaması ile ilgili kişilerin öğretmenlik uygulamasını ciddiye almamaları ve uygulama öğretmenlerinin, okul deneyiminin edinimi için yapılan etkinliklerin amaçlarının ve içeriklerinin farkında olmamaları. Benzer olarak Seçer, Çeliköz ve Kayılı (2010) tarafından; öğretim elemanları, öğretmenler ve okul öncesi öğretmen adayları ile yürütülen ve okul öncesi öğretmenliği okul uygulamalarında yaşanan sorunlar ve çözüm önerileri konulu araştırmada da uygulama öğretmenlerinin okul deneyimi ders içeriklerini bilmemeleri, uygulamaya devam ettikleri okul ile üniversite arasında işbirliği sağlanamaması, ulaşım zorluğu gibi benzer sonuçlar görülmektedir. Mevcut çalışmada ise bu çalışmadan farklı olarak lisans derslerinin teorikte kalması, diğer kurumlardan gelen öğretmen adayları, sınıf yönetim becerilerinde eksiklik, öğretmenlerin etkinlik sırasında müdahale etmeleri, sınıfta bulunan diğer yetişkinler, cinsiyete dayalı dalga geçilmesi ve staj uygulamasının yoğunluğunun yer aldığ 1 görülmektedir.

Değirmençay ve Kasap (2013)'ın çalışmasında lisans öğrencilerinin uygulamanın nasıl yapılması gerektiğine yönelik Fakültede hazırlanan rehber kılavuzun yeterli olmadığı sonucuna ulaşılmıştır. Yıldırım ve arkadaşları (2019)'na göre Fakülteden kaynaklı sorunlardan bir diğeri ise staj kapsamında atanan danışman hoca ile yaşanan iletişim sorunlarıdır. Raporları teslim alan öğretim elemanlarının süreç içerisinde adaylara yeterli ölçüde yardımcı ve destek olmadıklarını ve bu durumda iletişim sorununun yaşandığını belirtmişlerdir.

Duman (2013) tarafından yürütülen ve lisans öğrencilerinin uygulamada yaşadıkları sorunların araştırıldığı makalede; öğrencilerin alanlarında en fazla değerlendirme yöntem ve araçlarını kullanmakta 
zorlandıklarını göstermiştir. Öğrencilerin kazanımlara uygun değerlendirme biçimlerini belirleyebilme, kazanım göstergelere ulaşma düzeyini belirleyebilme ve uygun değerlendirme materyali hazırlayabilme konularında yetersiz oldukları bulunmuştur. Mevcut araştırmada ise lisans öğrencileri plan hazırlama konusunda sorun yaşadıklarını ifade ederken, özel olarak plan oluşturmanın alt boyutu olan değerlendirme yazma hakkında herhangi bir görüş belirtmemişlerdir.

Eraslan (2009)'ın öğretmen adaylarıyla yürüttüğü araştırma sonuçlarına göre; uygulama ögretmenleri günün büyük bir kısmında sınıfta yer almamakta, sınıfta oldukları sürelerde ise öğretmen adaylarına sınırlı sayıda ya da hiç geri dönüş sağlamadıkları tespit edilmiştir. Mevcut çalışmada da benzer olarak öğretmen adayları ve öğretim elemanları; öğretmenlerin uygulama sürecinde sınıfı terk etmelerinden bahsetmişlerdir. Ayrıca öğretim elemanları öğretmenlerin sınıfta bulunmamalarından dolayı öğretmen adaylarını etkili bir şekilde değerlendirmediklerini ifade etmişlerdir.

Seçer, Çeliköz ve Kayılı (2010)'e göre bu sorunların giderilmesine yönelik çözüm önerileri ise mevcut çalışmayla benzer olarak; üniversite ve uygulama okulları arasında işbirliği sağlanması ve uygulama saatlerinin artırılması yer almaktadır. Mevcut çalışmada farklı olarak yalnızca öğretmenlik uygulaması sürecine yönelik değil, aynı zamanda lisans eğitimine ilişkin öneriler de sunulmuştur.

Yıldız, Ulutaş ve Demiriz (2018) tarafından, öğretmenlik uygulamasına ilişkin öğretmen aday1 ve öğretmen görüşlerinin karşılaştırılmalı olarak incelendiği araştırma sonucunda; öğretmen adaylarının sınıf yönetimi ve çocukla iletişimimde desteğe ihtiyaç duydukları görülmüştür. Bu noktada mevcut araştırmayla karşılaştırdığımızda ise, Öğretmen adayından kaynaklı zorluklar açısından; öğretim elemanı ve öğretmenler ortak olarak öğretmen adaylarının çocuklarla iletişimde zorluk yaşadıklarını belirtmişlerdir. Ancak öğretmen adayları böyle bir zorluktan bahsetmemişlerdir. Bu durum öğretmen adaylarının çocuklarla iletişimde zorluklar yaşadıklarına dair farkındalıklarının olmadığını ya da öğretmen ve öğretim elemanlarının öğretmen adaylarının daha aktif olarak çocuklarla iletişime geçmelerine yönelik beklentilerinin olduğunu düşündürmektedir.

Öğretmenden kaynaklı zorluklar açısından paydaşların farklılaştığı noktaları incelediğimizde öğretmen adayları ve öğretim elemanları öğretmenden kaynaklı zorluklardan bahsederken öğretmenlerin ise kendilerinden kaynaklı herhangi bir zorluktan bahsetmedikleri dikkat çekmektedir. $\mathrm{Bu}$ durum öğretmenlerin öğretmenlik uygulaması sürecinde özeleştiri ya da öz değerlendirme yapmaya yönelik eğilimlerinin olmadığ 1 düşüncesini doğurmaktadır.

Üniversiteden kaynaklı zorluklar açısından paydaşların farklılaştığı noktaları incelediğimizde öğretmen adayları genel olarak uygulamayı yoğun ve iş yükünü fazla olarak değerlendirirken; bunun aksine öğretmenler bu sürecin çok daha uzun olması gerektiğini vurgulamışlardır. Öğretmenlerin mesleki tecrübelerine dayanarak; daha çok uygulama yapmanın öğretmen adaylarını öğretmenlik mesleğine hazırlamada önemli bir rolü olduğuna ilişkin inançlarından kaynaklandığı düşünülmektedir.

Atama süreci ile ilgili kaygılardan kaynaklı zorluklara ilişkin öğretmen adayları Kamu Personeli Seçme Sınavından (KPSS) bahsetmişlerdir. KPSS; öğretmen adaylarının öğretmen olarak atanabilmeleri için girmek zorunda oldukları ve aldıkları puanlar bazında sıralamaya girerek okullara yerleştirildikleri merkezi bir sınavdır. Bu sınav yoğun bir hazırlık dönemi gerektirmektedir. Haftada üç yarım gün öğretmenlik uygulamasına giden ve her gün için ayrı etkinlik planı hazırlıkları yapan öğrenciler; geri kalan zamanın sınava hazırlık için yetersiz olduğunu ve bu sebeple öğretmenlik uygulaması ve hazırlık sürecini birlikte yürütmekte zorluk yaşadıklarını ifade etmişlerdir.

Öğretmenler ve öğretim elemanlarının yaşadıkları zorluklar incelendiğinde öğretim elemanları, öğretmen ve üniversitenin beklentilerinin farklı olmasından kaynaklı birçok zorluk ifade ederken; öğretmenler bu zorluklara hiç değinmemişlerdir. $\mathrm{Bu}$ durumun temel nedeni, üniversitenin beklentilerinin öğretmenlere tam olarak yansıtılmaması ve ya yansıtılsa dahi bu beklentilere yönelik öğretmenlerin uygulama sürecine müdahil olunamamasıdır diye düşünülmektedir.

Ayrıca öğretim elemanlarının yaşanan zorluklarda "öğretmenlik tecrübelerinin olmaması" nı belirtmeleri; çalı̧̧manın dikkat çeken bulgularından biridir. Öğretim elemanının öğretmenlik deneyiminin olmaması, süreci yürütmede zorlanmalarına sebep olmaktadır.

Yaşanan zorlukların nedenleri incelendiğinde Öğretim elemanları öğretmen adaylarının programı tam olarak öğrenememiş olmalarını önemli bir neden olarak görürken; öğretmenlerin 
programa ilişkin herhangi bir ifadelerinin olmadığı görülmüştür. Öğretim elemanları haftalık planları detaylı olarak inceleyip dönütler verirken; öğretmenlerin planları değerlendirmemeleri, sadece verdikleri temalara dönük beklentilerinin olması ve öğretmen adaylarını yalnızca uygulama yaparken değerlendirmelerinden kaynaklı olarak paydaşlar arasında böyle bir farkın oluştuğu düşünülebilir.

Üniversiteden kaynaklı nedenlere baktığımızda, öğretim elemanları ve öğretmenler, öğretmen adaylarının yaşadıkları zorlukların nedeni olarak uygulama süresinin az olduğunu belirtirken; aksine öğretmen adayları bu sürecin uzun ve iş yükünün fazla olduğunu belirtmişlerdir. Öğretmenler ve öğretim elamanları uzun vadede nitelikli bir öğretmen yetiştirmek için öğretmenlik uygulamalarını firsat olarak görürken; öğretmen adaylarının uygulamaların gelecekteki kazanımlarını göz ardı ederek uygulamaları sadece bir ders olarak düşünüp uygulamayı sadece o dersin yükümlülükleri bakış açısıyla değerlendirmektedirler. Bununla birlikte Büyükgöze Kavas ve Bugay (2009) yaptıkları çalışmada öğretmen adaylarının öğretmenlik uygulamasının artırılmasını istedikleri ve uygulama sayılarını oldukça az bulduklarını ifade ettiklerini belirtmişlerdir. Bu farklılı̆̆ın nedeni bu çalışmada öğretmen adayları haftada üç gün uygulama yapmaktadır. Ayrıca Kavas ve Bugay (2009) çalışmalarında sadece okul öncesi öğretmenliği bölümünü değil diğer bölümleri de çalışma grubuna dahil etmişlerdir. Mevcut çalışmayla sonuçların farklılaşmasının nedeni farklı öğretmenlik alanlarından da kaynaklanabileceği düşünülmektedir.

Öğretmenden kaynaklanan nedenlere bakıldığında; öğretim elemanları yaşanan zorlukları ögretmenlerin niteliğgi ve rol model oluşlarıyla ilişkilendirirken; öğretmen adayları daha çok öğretmenlerin kendilerine yönelik tavır, tutum ve davranışlarla ilişkilendirmişlerdir. Seçer, Çeliköz ve Kayılı (2010) yaptıkları çalışmada öğretmenlerin öğretmen adaylarına karşı olumsuz tutum göstermeleri ve yardımcı personel gibi davranılmaları gibi benzer sonuçlara ulaşmışlardır. Buna benzer olarak Avcı ve İbret (2016) tarafından öğretmen adaylarının uygulamalarda karşılaştıkları sorunların irdelendiği araştırmada; uygulama öğretmenlerinin öğretmen adaylarını öğretmen gibi görmemesi ve çocukların öğretmen adaylarını bir otorite olarak görmemesi, uygulamadaki sorunlardan biri olarak belirtmektedirler. Demir ve Çamlı (2011) da çalışmasında, Sınıf ve Okul Öncesi Öğretmenliği öğretmen adaylarının uygulama okullarında idareci, uygulama öğretmeni ve öğrencilerden olumsuz yaklaşımlarla karşılaştıkları sonucuna ulamışlardır Bunun nedeni ise öğretmen adaylarının öğretmenlerle doğrudan sosyal ilişkiler kurup etkileşimli bir süreç yaşarken; öğretim elemanlarının öğretmenleri sadece öğretmenlik özellikleri bazında değerlendirip öğretmen ve öğretmen adayı arasındaki sosyal ilişkilerdeki davranış örüntüleri ve tutumları değerlendirme sürecine dahil etmemelerinden kaynaklandığı söylenebilir.

Öğretmen adaylarının okuldan kaynaklı nedenlerde okul idaresiyle iletişim eksikliğginden bahsetmesi araştırmanın dikkat çeken bulgularından biridir. Öğretmen adayları, uygulama sürecinde öğretmenden kaynaklı yaşadıkları zorlukların okul idaresi ile karşı1ıklı iletişime geçilememesinden kaynaklandığına inanmaktadırlar.

Öğretmenlik uygulamasına yönelik öneriler genel olarak değerlendirildiğinde; öğretim elemanlarının öğretmenlik uygulamasına yönelik öneriler sunduğu; öğretmenlerin plan ve uygulamanın süresine yönelik öneriler sunduğu; öğretmen adaylarının ise hem lisans eğitimi hem de uygulamaya dönük öneriler getirmişlerdir. Avc1 ve İbret (2016) yaptıkları çalışmada öğretmen adayları, öğretmenlik uygulaması dersinde yaşadıkları problemlere yönelik; uygulamalara başlanmadan önce uygulama öğretmenleri ile bilgilendirme toplantısının yapılması, ders danışmanlarının uygulama öğretmenlerine öğretmen adaylarının yapması gerekenleri açıklaması ve danışmanların uygulama sınıflarda öğretmen adaylarını aktif olarak gözlemlemeleri gibi çözüm önerilerinde bulunmuşlardır.

Genel olarak bakıldığında tüm paydaşların öğretmenlik uygulamalarını mesleki gelişimleri açısından değerli buldukları görülmektedir. Bunu yanı sıra bazı açılardan kişisel gelişimlerine de katkı sağladığını belirttikleri görülmektedir. Benzer olarak Değirmençay ve Kasap (2013)'ın Fen ve Teknoloji öğretmenliği, Okul Öncesi öğretmenliği ve Sınıf öğretmenliği bölümlerinde okumakta olan son sinıf öğrencilerinin Öğretmenlik Uygulaması derslerinin öğrencilerle iletişim kurma, geliştirme, sürdürme becerisi kazandığını, öğretmenlik mesleğine ilişkin becerileri kazanılmasında önemli bir ders olarak gördükleri ortaya çıkmıştır. Becit vd. (2009)'nin öğretmen adaylarıyla gerçekleştirdiği araştırmada; öğretmen adaylarının genel olarak öğretmenlik uygulamasına yönelik olumlu bir görüş sundukları, 
öğretmenlik mesleğine hazırlık açısından bu derslerin faydalı olduğu ve mesleğe ilişkin farkındalık sağladığı ortaya çıkmıştır.

$\mathrm{Bu}$ araştırmada öğretmenlik uygulamalarına ilişkin öğretmen, öğretmen adayı ve öğretim elemanlarının yaşadıkları zorluklar ve bu zorluklara ilişkin çözüm önerileri irdelenmiştir. Araştırmanın sonucunda; öğretmenlik uygulamalarında yaşanan sorunların temel olarak öğretmen adaylarından, öğretmenden, üniversite ve lisans eğitiminden, atama süreci ile ilgili kaygılardan ve okuldan kaynaklı nedenlerden dolayı ortaya çıktığı görülmüştür. Gözlem notları ve kontrol listelerinden elde edilen bulgular da genel olarak tüm paydaşların görüşleriyle paralellik göstermektedir.

Çalışmanın bulgularında öğretmenlik uygulamalarının daha etkili ve verimli olması adına lisans eğitimine ve öğretmenlik uygulamasına yönelik öneriler detaylı olarak paydaşlar bazında sunulmuştur. Bu bölümde ise bu öneriler temel alınarak daha kapsamlı ve genel öneriler sunulacaktır.

Öğretmenlik uygulamasında yaşanan zorluklar uygulamanın niteliğini etkilemektedir. Öğretimdeki niteliği artırmak için öncelikli olarak;

Öğretmen adayları ve öğretim elamanları ortak görüş olarak yaşanan zorlukların nedenlerinde lisans eğitimleri sürecinde aldıkları derslerin alan hocaları tarafından verilmemesinden kaynaklandığını belirtmişlerdir. $\mathrm{Bu}$ bağlamda yeterli öğretim üyesi olmayan üniversitelerde lisans programının açılmaması önerilmektedir.

Öğretmenlik uygulaması Millî Eğitim Bakanlığı ve üniversitelerin ortak sorumluluğunda yer almaktadır. $\mathrm{Bu}$ iki kurum arasında öğretmen adaylarından beklenen görev ve sorumluluklar doğrultusunda uyumun olmamasından dolayı öğretmen adayları stajlarda sorun yaşadıklarını belirtmişlerdir. $\mathrm{Bu}$ bulgu doğrultusunda uygulamalarda MEB ile iş birliği yapılarak öğretmenlere öğretmenlik uygulamasının amacı, öğretmen adayının görev ve sorumluluklarına ilişkin bilgi ve eğitim verilmesinin sorunlar için çözüm olacağı düşünülmektedir. Ayrıca öğretmenlik uygulamasına yönelik tüm paydaşların (okul, üniversite, YÖK ve MEB) iş birliği içinde olması, bu iş birliğinin sağlanmasına yönelik politikalar geliştirilmesi önerilmektedir.

Öğretmen adayları ve öğretim elemanları lisans derslerinin teorik ağırlıklı olduğunu ve uygulamaya dönüş̧ürmede zorluk yaşadıklarını ifade etmişlerdir. Bu bulgu temelinde lisans derslerinin teorik ve uygulama olarak iki bölümde verilmesi önerilmektedir. Yine bu bulguya paralel olarak öğretmenlik uygulamalarının son sınıfta yoğun olarak verilmesi yerine lisans eğitiminin tüm dönemlerinde uygulamaların gerçekleştirilmesinin teorik olarak alınan derslerin uygulamaya dönüştürülmesinde etkili olacağı düşünülmektedir.

Ayrıca yine öğretmen adayları ve öğretim elemanları yaşanan zorlukların; öğretmenlik uygulamasında rehberlik eden öğretim elemanlarının öğretmenlik tecrübelerinin olmamasından kaynaklandığını belirtmişlerdir. Öğretmenlik uygulamalarında kalitenin artırılması ve yeterli desteğin sağlanabilmesi için öğretmenlik deneyimi olmayan öğretim elemanlarının eğitimin bir parçası olarak öğretmenlik deneyimine tabi tutulmasının gerektiği düşünülmektedir.

Öğretmen adaylarının uygulama okullarından ve öğretmenlerinden yeterli rehberlik alamamaları, okul idaresinin öğretmen adayı ile iletişime geçmemesi, gösterişli ve görsel etkinliklere çok önem verilmesi, sınıfta yalnız kalmaları gibi uygulama okulu ve ögretmenlerden kaynaklı zorluklar yaşadıkları bulgusuna ulaşılmıştır. Bu bağlamda uygulama okul ve öğretmenlerin seçiminde ölçütler ya da standartların belirlenmesi ve bu kriterlere uygun okulların seçilmesi veya okul ve öğretmenlere bu konuda hizmet içi eğitim sunulması önerilmektedir. 


\section{Kaynakça}

Avcı, E. K. ve İbret, B. Ü. (2016). Öğretmenlik uygulaması-II dersine ilişkin okul öncesi öğretmen adaylarının görüşlerinin değerlendirilmesi. Kastamonu Ĕ̆itim Dergisi, 24(5), 2519-2536.

Baştürk, S. (2007). Ögrretmen adaylarının ögretmenlik uygulaması dersiyle ilgili deneyimleri ve önerileri. 16. Ulusal Eğitim Bilimleri Kongresinde sunulan bildiri, Gaziosmanpaşa, Tokat.

Becit, G., Kurt, A. A. ve Kabakçı, I. (2009). Bilgisayar öğretmen adaylarının okul uygulama derslerinin yararlarına ilişskin görüşleri. Anadolu Üniversitesi Sosyal Bilimler Dergisi, 9(1), 169-184.

Beck, C. ve Kosnik, C. (2002). Components of a good practicum placement: Student teacher perceptions. Teacher Education Quarterly, 29(2), 81-98.

Boz, N., ve Boz, Y. (2006). Do prospective teachers get enough experience in school placements? Journal of Education for Teaching, 32(4), 353-368.

Brooks, V. (2006). A 'quiet revolution'? The impact of training schools on initial teacher training partnerships. Journal of Education for Teaching, 32(4), 379-393.

Bulut, S., ve Demircioğlu, H. (2000). Kimya öğretmen adaylarının öğretmenlik uygulaması deneyimi. Hacettepe Üniversitesi Eğitim Fakültesi Dergisi, 19, 194-200.

Burton, D. (1998). The changing role of the university tutor within school-based initial teacher education: issues of role contingency and complementarity within a secondary partnership scheme. Journal of Education for Teaching, 24(2), 129-146.

Büyükgöze Kavas, A., ve Bugay, A. (2009). Öğretmen adaylarının hizmet öncesi eğitimlerinde gördükleri eksiklikler ve çözüm önerileril eri. Pamukkale Üniversitesi Eğitim Fakültesi Dergisi, 25(25), 13-21.

Cansaran, A., İdil, Ö. ve Kalkan, M. (2006). Fen bilgisi eğitimi anabilim dallarındaki "Okul Deneyimi” uygulamalarının değerlendirilmesi. Gazi Ĕ̈itim Fakültesi Dergisi, 26(1), 83-99.

Çetintaş, B. ve Genç, A. (2005). Almanca öğretmen adaylarının öğretmenlik uygulaması derslerine ilişkin görüş ve deneyimleri. Hacettepe Üniversitesi Ĕgitim Fakültesi Dergisi, 29, 75-84.

Çiçek, Ş. ve İnce, L. (2005). Öğretmen adaylarının öğretmenlik uygulaması sürecine ilişkin görüşleri, H.Ü. Spor Bilimleri Dergisi, 16 (3), 146-155.

Değirmençay, Ş. A., ve Kasap, G. (2013). Okul deneyimi ve öğretmenlik uygulaması derslerine ilişkin öğretmen adaylarının görüşleri. Adnan Menderes Üniversitesi Ĕgitim Fakültesi Eğitim Bilimleri Dergisi, 4(2), 47-57.

Demir, Ö. ve Çamlı, Ö. (2011). Öğretmenlik uygulaması dersinde uygulama okullarında karşılaşılan sorunların sınıf ve okul öncesi öğretmenliği öğrenci görüşleri çerçevesinde incelenmesi: Nitel bir çalışma. Uludağ Üniversitesi Ĕ̈itim Fakültesi Dergisi, 24(1), 117-139.

Duman, G. (2013). Okul öncesi öğretmenliği lisans programı öğretmenlik uygulaması derslerinin öğrenci boyutunda değerlendirilmesi. Kastamonu Ĕgitim Dergisi, 21(4), 1661-1674.

Eraslan, A. (2009). İlköğretim matematik öğretmen adaylarının" öğretmenlik uygulaması" üzerine görüşleri. Necatibey Eğitim Fakültesi Elektronik Fen ve Matematik Ĕgitimi Dergisi, 3(1), 207 221.

Ergün, M. ve Özdaş, A. (1999). Okul gözlemi ve uygulama çalışmalarının öğretmen adayları üzerindeki etkisi. Afyon Kocatepe Üniversitesi sosyal Bilimler Dergisi, 3, 115-119.

Genç, A., Sarıçam, C., ve Bakır, N. (2001). Alman dili eğitimi anabilim dallarında okul deneyimi I dersinin uygulanmas1. Hacettepe Üniversitesi Eğitim Fakültesi Dergisi, 21, 41-51.

Güzel, H. ve Cerit, N. (2006). Tezsiz yüksek lisans alan ögrretmenliği ögrencilerinin okul deneyimi etkinliklerinin karşılaş̧tırılması. VII. Ulusal Fen Bilimleri ve Matematik Eğitimi Kongresinde sunulan bildiri. Gazi Eğitim Fakültesi, Ankara.

Kasapoğlu, K. (2015). A review of studies on school experience and practice teaching in turkey. Hacettepe Üniversitesi Eğitim Fakültesi Dergisi [Hacettepe University Journal of Education], 30(1), 147-162.

Kavas, A. B. ve Bugay, A. (2009). Öğretmen adaylarının hizmet öncesi eğitimlerinde gördükler eksiklikler ve çözüm önerileri. Pamukkale Üniversitesi Ĕ̆itim Fakültesi Dergisi, 25(25), 13 21.

Kı1ıç, D. (2004). Öğretmenlik uygulaması dersinin öğretmen adayları üzerine etkisinin değerlendirilmesi. Kazım Karabekir Eğitim Fakültesi Dergisi, 10, 172-184. 
Kiraz, E., ve Yıldırım, S. (2007). Enthusiasm vs. experience in mentoring: A comparison of turkish novice and experienced teachers in fulfilling supervisory roles. Asia Pacific Education Review, 8(2), 250-261.

Koç, C., ve Yıldız, H. (2012). Öğretmenlik uygulamasının yansıtıcıları: Günlükler. Eğitim ve Bilim, 37(164), 223-236.

Köroğlu, H., Başer, N. ve Güneş, Y. (2000). Okullarda uygulama çalışmalarının değerlendirilmesi. Hacettepe Üniversitesi Ĕ̈itim Fakültesi Dergisi, 19, 85-95.

Merriam, S. B. (2013). Nitel Araştırma Desen ve Uygulama İçin Bir Rehber (Çev. S. Turan). Ankara: Nobel Yayınları.

Seçer, Z., Çeliköz, N. ve Kayılı, G. (2010). Okul öncesi öğretmenliği okul uygulamalarında yaşanan sorunlar ve çözüm önerileri. Yüzüncü Yll Üniversitesi, Eğitim Fakültesi Dergisi, 7(1), 128-152.

Şahin, E. (2003). Okul öncesi eğitimi öğretmenliği programında öğrenim gören öğretmen adayları ile uygulama okullarındaki öğretmenlerin mesleki uygulamalara ilişkin bakış açıları. Eğitim Araştırmaları Dergisi, 4(13), 1.

Şişman, M. ve Acat, B. (2003). Öğretmenlik uygulaması çalışmalarının öğretmenlik mesleğinin algılanmasındaki etkisi, Frrat Üniversitesi Sosyal Bilimler Dergisi, 13 (1), 235-250.

Turgut, M., Y1lmaz, S. ve Firüzan, A. R. (2008). Okul deneyimi uygulama sürecinin değerlendirilmesi üzerine bir araştırma. Üniversite ve Toplum Dergisi, 8(2), 1-26.

Ünver, G. (2003). Öğretmenlik uygulamasında işbirliği: bir durum çalışması, Gazi Üniversitesi Gazi Ĕ̈itim Fakültesi Dergisi, 23 (1), 87-100.

Yildırım, R. G., Özyılmaz Akamca, G., Ellez, A. M., Karabekmez, S., ve Bulut Üner, A. N. (2019). Okul öncesi öğretmen adaylarının okul deneyimi ve öğretmenlik uygulaması derslerine ilişkin görüşlerinin incelenmesi. Journal of Higher Education ve Science/Yüksekögretim ve Bilim Dergisi, 9(2), 306-316.

Yıldız, R., Ulutaş, İ., ve Demiriz, S. (2018). Okul öncesi öğretmenliği lisans programında yer alan "öğretmenlik uygulaması" dersine iliş̧in görüşlerin karşılaştırılması. Gazi Üniversitesi Gazi Ĕ̈itim Fakültesi Dergisi, 38(3), 869-886.

Yükseköğretim Kurulu (1999). Türkiye'de öğretmen eğitiminde standartlar ve akreditasyon. Anakara: Öğretmen Eğitimi dizisi. 


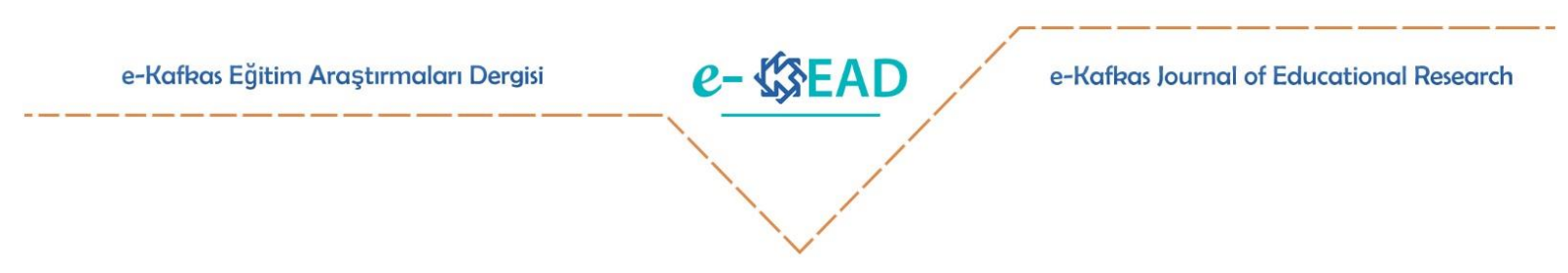

\section{Examination of the Difficulties of Pre-school Teacher Candidates, Teachers and Teaching Staff in the Process of "Teaching Practice"}

\section{Esra Akgül}

Fulya Ezmeci

\section{Berrin Akman}

To cite this article: Akgül, E., Ezmeci, F. ve Akman, B. (2020). Okul öncesi öğretmen adaylarının, öğretmenlerinin ve öğretim elemanlarının "öğretmenlik uygulaması" sürecinde yaşadıkları zorlukların incelenmesi. e- Kafkas Ĕgitim Araştırmaları Dergisi, 7, 167-184. doi:10.30900/kafkasegt.701585

Research article

Received: 10.03 .2020

Accepted: 12.07 .2020

\section{Introduction}

This research aims to determine the difficulties encountered in teaching practices and the ways to improve them. For this purpose, answers to the following questions were sought:

1- What are the difficulties experienced in Teaching Practice?

2- What are the reasons of these difficulties?

3- What are the solution suggestions for these difficulties?

4- What are the professional contributions of Teaching Practice?

5- What kind of similarities and differences are on the difficulties, causes and solution suggestions based on stakeholders?

\section{Method}

This study was designed in a basic qualitative research design. In the study, Interviews were made with 18 teacher candidates studying at a public university primary education, 19 preschool teachers - with university degrees and their practice ranging from 6 to 36 years- in the classes where teacher candidates practice, 8 lecturers systematically observing teacher candidates' practices and giving feedback them.

In the process of data collection, "Interview Form", developed by researchers, consisting of semi-structured questions and Prepared separately for teacher candidates and teachers was used. While creating the observation form and checklist; The difficulties experienced by teacher candidates are listed according to the opinions of teacher candidates, teachers and lecturers. Two different dimensions have emerged regarding the plans and implementation process prepared in this list. While the checklist was created for the dimension for preparing the plan, the observation form was generated for the dimension for practicing.

The interviews were held face to face and each lasted approximately 25 minutes. observation form and checklist - Prepared by analyzing the data obtained from the interviews, are filled in by observing at least and half day for 8 weeks and by examining all the plans (864 activity plans) prepared by teacher candidates in this process.

Inductive analysis method was used in the analysis of the data. To ensure the reliability of the research, it was blindly examined and analyzed by three researchers, then the researchers came together and compared the codes. On the codes attributed to different categories, the codes that all three researchers agreed were decided. 


\section{Findings}

Findings, obtained as a result of analysis; were gathered under four titles as teacher candidates' difficulties, the difficulties faced by teachers and lecturers, the reasons for the difficulties experienced and practice suggestions and professional achievements.

As a result of the research, It has been founded that the problems experienced in teaching practices arise mainly due to teacher candidates, teachers, university and undergraduate education, concerns about the appointment process and school-related reasons. It was observed that Teacher candidates had difficulty in these issues: courses remain in theory, teacher candidates coming from other institutions, lack of classroom management skills, teachers' intervention during the activity,other adults in the classroom, gender-based bully, teachers' lack of knowledge about the content of school experience, lack of cooperation between the school and the university and The intensity of the internship application.. Solution suggestions for eliminating the problems are firstly cooperation between universities and practice schools, then Increasing the hours of practice at school. In addition, rotation between schools in applications, increasing the quality of The content of the courses given in undergraduate education and Ensuring the effectiveness of the feedbacks received by teacher candidates at practice schools are the other solution suggestions.

\section{Discussion, Conclusion and Recommendations}

In the research carried out by Seçer, Çeliköz and Kayılı (2010), similar results are observed that is the teachers do not know the course contents, the cooperation between the school and the university and the difficulty of transportation. In addition, in the current study, it is observed that undergraduate courses remain in theory, teacher candidates from other institutions, lack of classroom management skills, teachers' intervention during the activity, other adults in the classroom and genderbased bully.

According to Seçer, Çeliköz and Kayılı (2010), the solution suggestions to overcome these problems are similar to the current study; Cooperation between universities and application schools and increasing the application hours are included. Unlike the current study, suggestions for not only the teaching practice process but also undergraduate education were presented.

When we examine the points where the stakeholders differ in terms of difficulties arising from the teacher candidate, the instructor and teachers stated that the teacher candidates had difficulties in communicating with the children. However, teacher candidates did not mention such a difficulty. This suggests that pre-service teachers are not aware that they have difficulties in communicating with children, or that teachers and teaching staff have expectations from pre-service teachers to communicate more actively with children.

When we examine the points where Stakeholders differ in terms of difficulties caused by the teacher; when pre-service teachers and lecturers talk about the difficulties caused by the teacher, preservice teacher and lecturers talk about the difficulties caused by the teacher. this leads to the idea that teachers do not have a tendency to self-criticize or self-asess during the teaching practice process.

When the Challenges of Teachers and Instructors are examined, while faculty members express many difficulties due to the different expectations of the teacher and the university; teachers never addressed these difficulties. The main reason of this situation is thought that the expectations of the university are not fully reflected to the teachers and that even if they are reflected, teachers cannot be involved in the application process towards these expectations.

In addition, lecturers state that they have "no teaching experience" in the difficulties; is one of the remarkable findings of the study. Lack of teaching experience of the lecturers causes difficulties in conducting the process.

In order to increase the quality of teaching, primarily;

- Undergraduate programs should not be opened at universities that do not have enough faculty members. 
- To provide teachers with information and training on teaching practice in cooperation with MEB for internship practices.

- Undergraduate courses given in two parts as theoretical and practical.

- Instead of giving intensive teaching practices in the final year, the implementation of all the periods of undergraduate education

- Implementation of criteria or standards in the selection of schools and teachers

- Cooperation of all stakeholders (school, university, YÖK and MONE) for teaching practice. 